\title{
大腿骨々幹部粉砕骨折におけるエンダー髄内釘固定法の経験
}

\author{
大野病院整形外科 \\ 大 梘 伸 吾・金 井成 行 \\ 夫猛・森下常 一

\section{Two Cases of Ender Nailing for Comminuted Femoral Shaft Fractures} \\ by \\ Shingo Otsuki, Shigeyuki Kanai, Takeshi Fu \\ and Tsunekazu Morishita \\ Department of Orthopaedic Surgery, \\ Ohno Hospital, Osaka
}

\begin{abstract}
Ender nailing was used in two comminuted femoral shaft fractures. The fractures were classified according to Aoyagi's classification. The first case was a 77 year-old female with a comminuted fracture of Aoyagi's type III. Five months after surgery,the fracture was healed with external rotatory deformity. The second case was 23 -year-old female with a comminuted fracture of Aoyagi' s type $\mathrm{V}$.

Three months after surgery,the fracture was healed with $1.3 \mathrm{~cm}$ shortening. The patients were allowed early weight-bearing and early mobilization. Therefore Ender nailing is a suitable treatment for these fractures.
\end{abstract}

\section{は じめに}

今回，われわれは，高度な大腿骨々幹部粉砕骨折に 対し，エンダー髄内釘固定法を応用した観血的治療を 行い良好な骨痢合を得ることができたのでその小経験 に若干の考察を加えて報告する，症例は 2 例 2 肢であ る.

\section{症例}

症例 $1: 77$ 才，女性.

主訴: 両大腿部痛.

現病歴：パーキンソン病および両膝 OAにより歩行 にも手押し車が必要であり某院にて加療中であった. 交通事故にて左大腿骨々幹部粉砕骨折，右大腿骨頸部 外側骨折，骨盤骨折を受傷した。即日，当科に救急搬 送された.

経過：受診時即にショック状態であり，全身状態の 改善を計った.受傷 13 日目に両大裉骨々折に対しエン
ダー髄内釘固定術を行った. 術後 4 カ月にてほぼ骨癒 合は完成したが，両側に外旋変形を残している.

手術所見：左粉砕骨折に対して，エンダー釘 2 本を 原法に従って打ちこんだ. 粉砕骨折部には小切開を加 え骨片の整復および釗の導入を行った。骨片は愛護的 に扱い骨膜を温存する様に努めた，粉砕骨折の手術時 間は 1 時間 50 分出血量は $430 \mathrm{ml}$ であった.

症例 $2: 23$ 才, 女性.

主訴：右大腿部痛右肩痛.

現病歴：交通事故にて右大腿骨々幹部粉砕骨折, 右 肩中骨頸部骨折および下顎骨折を受傷した(図 1 )。他 院にて応救処置がなされ受傷後 6 日目に当科入院とな った.

経過：肩中骨々折，下顎骨折は保存的に治療した。 受傷より 13 日目に右大腿骨々折に対しエンダー䯣内釘 固定を行った. 術後 3 カ月にて骨癒合はほぼ完成し変 形も認めない(図 2 ). 術後 7 カ月にて抜釘を行ったが 膝の ROM 障害はなく, 健側との比較で $1.3 \mathrm{~cm}$ の下腿 短縮がみられた（図 3 )。 


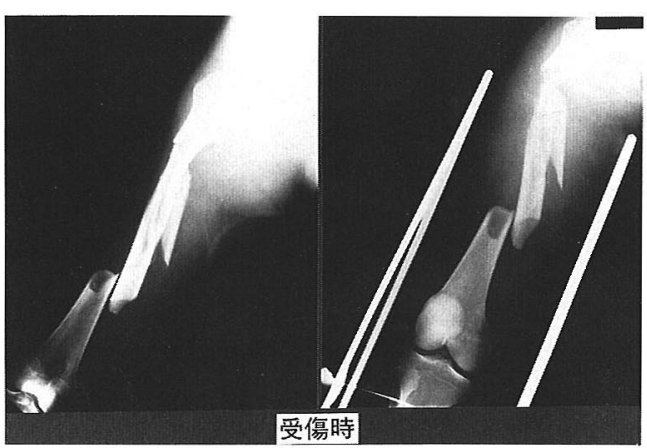

図 1 症例 $2:$ 受傷時

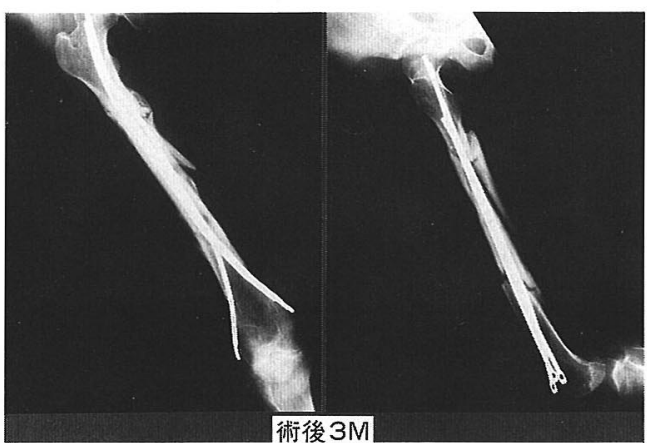

図 2 症例 $2:$ 術後 3 カ月でほぼ骨瘾合を得た。

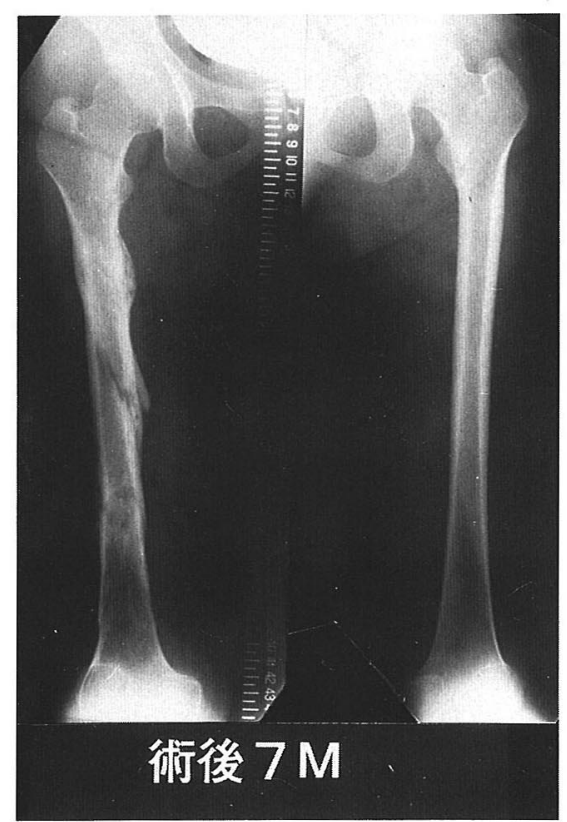

図 3 症例 2 : 術後 7 力月で抜釘. $1.3 \mathrm{~cm}$ の短縮を認 めたが膝 ROM 障害や回旋变形はない.
手術所見：牽引手術台を用いた。大腿骨遠位内側よ り 2 本のエンダー釘を打ちこんだ。さらに外側より大 転十方向に向けて釘の打ち込みを行った。粉砕骨折部 には小切開を加えて骨片の整復およびエンダー釘の導 入を行った。手術時間は 1 時間 40 分, 出血量は $300 \mathrm{ml}$ であった。

考察

いわゆる大骨粉砕骨折のなかでも青柳らによる分類 ではIII型およびV型が治療上問題となる事ことが多い とされている11。症例 1 はIII型, 症例 2 はV 型に当ると 考えられる。粉砕骨折では症例に応じて様々な治療法 が諸家により選択されているが，観血的治療の多くは 髄内釗固定が用いられているようである。青柳らは， キエンチャー釘十横螺子固定にて良い結果を得たとし ている 仮骨形成を持ってから第 2 次の手術を行うという報告 もある ${ }^{3)}$.片田らは様々な型の大腿骨々幹部骨折に対し てエンダー釘固定を応用し良い結果を得たとしている2 エンダー釘固定は，長管骨々幹部への応用において， 回旋力に対する固定性が弱いのではないかと懸念する むきもあるが，松倉らは，七トホルマリン固定大腿骨 を用いた実験で大転子方向への釘の打ち込みにより回 施力に対する固定性も充分得られるとしている ${ }^{4)}$. 症例 1 では使用したエンダー釘が 2 本と少なく大転子方向 への釘の打ち込みも行っていないため回旋変形をきた したものと反省している。一方，こうした観見的治療 の他に SARMIENTO らは functional brace を用いた 保存的治療を行っているが大腿骨近位 $1 / 3$ には良い適 応がなく，さらに仮骨形成をみるまでの数週間は直達 牽引下での臥床が必要である6).

\section{ま と め}

高度な大腿骨々幹部粉砕骨折に対し，エンダー釘固 定を応用し良好な骨癒合を得た。われわれは，これら の症例に対する治療経験は少ないが，患者への侵襲も 少なく早期離床を果たすためにもエンダー釘固定の応 用は有用と考える。

\section{参考 文 献}

1）青柳孝一：大腿骨骨幹部粉砕骨折の分類と治療。整形 外科, $32: 1821-1828,1981$.

2）片田重彦：大腿骨骨幹部骨折に対する Ender nailing 
法の手術手技の検討. 整形外科, $37: 449-456,1986$.

3) Kunner, E.: Der Oberschenkel-Mehrfragmentenbruch in Schaftbereich. Dtsch. Med. Wochenshr. 94 : 645, 1969.

4）松倉 登：下肢の粉砕骨折に対する治療経験. 中部整 災誌, $28 ： 1763-1764,1985$.

5）中村英健：大腿骨骨幹部粉砕骨折に対するいわゆる delayed operation の治療成績について.日災医誌, 21： 38, 1973.

6) Sarmiento Augusto: Functional bracing of tibial and femoral shaft fractures, Clin. Orthop. $82: 2-13$, 1972.

質 問産業医科大学 伊地知正光

短縮変形予防に，どの位の期間牽引を併用していま すか.

解 答 大野病院 大梘 伸吾

今回の症例には術後牽引は併用しなかった。 